\title{
Entrance examinations and TEFL in Brazil: a case study ${ }^{1}$
}

\author{
Matilde V. R. Scaramucci \\ Universidade Estadual de Campinas
}

\begin{abstract}
Este artigo é um relato de uma pesquisa de natureza qualitativa e exploratória cujo objetivo é investigar o impacto da prova de Inglês do vestibular da Universidade Estadual de Campinas nas atitudes, comportamentos e ações de professores em três contextos de ensino médio dessa cidade: escola pública, particular e curso preparatório. $\mathrm{O}$ estudo triangula informações coletadas a partir de diferentes perspectivas e métodos. Impactos de intensidades distintas são observados nos cenários investigados, constituindo evidência que permite concluir que a influência que o exame em questão exerce no ensino não é determinista.

This article reports on an exploratory qualitative case study aimed at investigating the impact of an EFL reading ability exam on the attitudes, behaviors and actions of teachers in three different settings of EFL teaching at the secondary level in Campinas, São Paulo State, Brazil. The exam is part of the entrance examinations administered by State University of Campinas since 1987. The study triangulates information collected from different perspectives and methods. Impacts of different intensities are observed in the cenarios investigated, which may be taken as evidence to conclude that the effect of this test on teaching is not deterministic.
\end{abstract}

\section{Introduction}

The influence of testing and assessment on teaching and learning, known in the literature as washback (or backwash), has been a matter of debate since the publication of the instigating paper by Alderson \& Wall (1992) Does washback exist? Despite the interest the topic has aroused and the many contributions produced since then (Alderson \& Hamp-Lyons, 1996; Bailey, 1996; Cheng, 1999; Hamp-Lyons, 1997; Messick, 1996; Wall 1996; Wall \& Alderson, 1992, Watanabe, 1996, among others) one cannot affirm that the debate is resolved, as there is not yet a satisfactory theory to describe and explain its mechanisms. It could not have been otherwise, however, considering the complexity of the issues involved. What seems distinctive in the recent literature on washback is the awareness that the only way to produce a theory is through evidence that can counter the speculations that characterized the area some years ago.

Many studies conducted around the world, including the current one, were motivated by this search for evidence. I believe the main contribution of those studies is not the value of the individual attempts to produce a theory of washback but a composite description of its mechanisms in different contexts, so that patterns and regularities can be documented and a theory formulated.

\footnotetext{
${ }^{1}$ I would like to acknowledge FAPESP - Fundação para o Apoio à Pesquisa do Estado de São Paulo São Paulo [The State of São Paulo Research Foundation] - for providing the funding for this research project. I wish to thank also my colleague Joanne Busnardo for her helpful comments on an earlier version of this paper.
} 
This article reports on an exploratory case study conducted from 1995 to 1997 aimed at investigating the impact of an EFL reading ability exam on three different settings of EFL teaching at the secondary level in Campinas, São Paulo State, Brazil. The exam is part of the entrance examinations or "exames vestibulares" administered by State University of Campinas (Unicamp) since 1987. The context of university entrance examinations in Brazil could be considered a high-stakes testing situation because of the importance those exams have within the Brazilian educational system and, as such, a site of great potential for investigating washback.

This chapter is divided into several parts. First I contextualize the research, describing the Unicamp exam within the Brazilian university entrance examination system and the status of EFL and TEFL in that context. Next I present the study, describing the methodology and procedures for data collection and analysis. I then go on to present the results, conclusions and implications.

\section{The Brazilian university entrance examination system and the Unicamp examination}

Despite the long tradition university entrance examinations ${ }^{2}$ have had in the Brazilian educational system, there is no record to date of published studies aimed at investigating their impact on the teaching or learning preceding them. In this sense, this study, along with Gimenez (1999), conducted in the context of State University of Londrina examination, could be considered a beginning.

As in the case of the Japanese entrance examinations reported by Watanabe (1996), access to Brazilian universities via examination is extremely competitive, as the number of places is insufficient. Most of the students who fail to enter their target university after graduation from high-school will study another year to take the next year's entrance exam, contributing to the increase in the number of applicants in the following year.

Universities in Brazil fall into two categories: public or private ${ }^{3}$. The public institutions are either state or federal. The situation here is similar to that in Japan, as described by Watanabe (1996), i.e., there is a ranking of universities, and a widespread belief that entering high-ranking ones is a guarantee to better jobs after graduation. As the public institutions are regarded as the best ones, the competition to enter these universities is even greater, which makes these exams high-stakes.

One controversial aspect of this educational system is that private secondary education has a better reputation than public education; consequently, students from private institutions usually have had greater chances of entering high-ranking public universities, especially for high-status courses such as Medicine ${ }^{4}$. A number of unfavorable conditions present in the public system have been blamed for this situation: classes with too many students, unmotivated teachers and students, poor working conditions and low salaries, among others.

Due to great competition for admission to universities and the students' need to be prepared for more than one examination to increase their chances of passing, many private extracurricular institutions (cramming courses) called "cursinhos" (literally

\footnotetext{
${ }^{2}$ University entrance examinations have always been a matter of debate in Brazil. Attempts have been made by the Ministry of Education to replace it with the Secondary Level National Exam (ENEM).

${ }^{3}$ According to the Ministry of Education (2000), there are 156 universities in Brazil, of which 72 are public e 84 are private. There are also 1,122 colleges, of which 1,003 are private and 109 are public.

${ }^{4}$ Approximately 120 candidates for one place, although there is a variation in these figures from one year to the other.
} 
"short intensive courses") offer preparation for several entrance examinations at a time. These "cursinhos" may last from 5-6 months up to one whole year. There are, however, institutions that offer also separate preparation for the different examinations.

The State University of Campinas is the youngest of the three state universities of São Paulo State. Located in Campinas, which is the second largest city in São Paulo State, it is a high-ranking university with highly competitive examinations, taken every year by approximately 33,000 students from all over the country. Despite the good reputation the examination has had, however, there have not been validation studies published to date.

The current examination format, produced by a permanent committee composed mostly of faculty members, was administered for the first time in 1987. It was at the time considered innovative for introducing written essays and replacing the traditional multiple choice questions with open-ended questions. Before being reformulated, it used to be similar to the other university entrance examinations in the country, criticized for encouraging mechanical practices and memorization of formulas. In its new version, the exam aims at assessing not only the contents acquired at the secondary level but also higher-order cognitive skills such as the ability to organize and express ideas clearly, to establish relationships and interpret results, formulate problems and develop hypotheses. The reformulation has been justified as a means of selecting students with a different profile and, at the same time, as explicitly stated by its proponents, of promoting greater interaction with the secondary level, providing guidelines for the realignment of the curriculum (Candidate's manual, 1996).

As with most university entrance examinations in Brazil, the Unicamp exam has two stages. The first, taking place at the end of November ${ }^{5}$, consists of a written essay and 12 questions in each of the subjects of Mathematics, Portuguese, Biology, History, Geography, Physics and Chemistry, taken by all the candidates regardless of the target study area. Students who succeed at this stage go on to the second one, which takes place in January, taking exams in each of the subjects of Portuguese Language and Portuguese Literature, Biology, Chemistry, Physics, Mathematics, Geography, History and Foreign Language. On the average, there is a drop of one third in the number of candidates in the second stage ${ }^{6}$.

\section{EFL in Brazil and in the Unicamp examination}

English is taught in Brazil from grades 5 to 8 of primary level education and in the last three grades of secondary level in private and public schools. Despite the prestige it has as the dominant foreign language of science and technology, and its function as a gatekeeper to getting jobs and positions of prestige in society, the teaching of English, especially in the public schools, has been in general of poor quality and, as a result, the levels of proficiency attained are frequently very low ${ }^{7}$. In this context, there is a belief shared by many teachers as well as students that "it is impossible to learn English at school". Successful learning is believed to be attained in private language centers or after living for a certain period in the country where the foreign language is spoken. Therefore, English as a discipline can be said to have a different status when compared to the other disciplines in the curriculum. The lack of

\footnotetext{
${ }^{5}$ The school year starts in March.

${ }^{6}$ Figures made public in the newspapers every year.

${ }^{7}$ Many studies have been conducted in this context. See, for instance, Consolo (1990), among others.
} 
prestige EFL has, especially in the public educational system, seems to be reflected in the foreign language exam, as it is not in general considered to be an important subject for which a minimum score has to be obtained ${ }^{8}$. However, a good score at the foreign language exam can be decisive for students aiming at high-ranked courses such as Medicine.

French is the other foreign language usually required in Brazilian university entrance examinations and at Unicamp as well. Although the candidates may choose between the two, about $98 \%$ take the English exam.

Each university decides on the nature of the exam as well as on its specifications and guidelines. At Unicamp the English and French exams focus on reading ability, viewed as a means to access technical, cultural and scientific information and, therefore, essential for studying at the university. Although considered by many to be one of the positive aspects of the new exam, a focus on reading ability has been criticized by others on the grounds that it narrows down the curriculum and curbs the development of other skills.

The English exam, as in the other subjects areas, consists of 12 open-ended question items, written in Portuguese, with the rubrics also in Portuguese, covering a range of authentic texts of different genres, topics, lengths, sources and levels of difficulty. The answers are to be given in Portuguese, as the aim is reading comprehension and not written production.

The items, varying in levels of difficulty and reading purpose, are aimed at different levels of comprehension and sub-skills such as reading for gist or specific details, scanning for locating explicit information, inferring of lexical items, reconstructing arguments, recognizing relations and contradictions between texts, including therefore, explicit and implicit or inferential aspects, global and local comprehension as well as micro and macro level skills.

The exam guidelines are briefly presented in a booklet called "the Candidate's manual", which contains the view or definition of reading which underlies the exam and the list of sub-skills assessed by the items. Inspection of past exam papers is possible as they are made public every year. Reading is presented as an active process of meaning construction, which requires an active reader, who is able to use previous knowledge to interact with texts. The following excerpt is offered as an example of the technical terminology used in one part of the document: "to be able to recognize elements of discursive nature, such as, for instance, those which have to do with the processes of discourse and utterance construction: how the uttering subject and how the subject to whom the utterance is directed are constituted in discourse, and how certain discursive strategies are used in discourse" (1996:21).

Grading is done centrally by a team of approximately 35 markers, selected from among language teachers and graduate students, monitored by a chief examiner, who is in charge of answering questions, clarifying grade schemes and promoting discussions as to what should be considered acceptable responses. Graders go through a selection process in which criteria such as English proficiency, previous experience in teaching and marking are taken into consideration, besides performance in a 45-hour course, where familiarization with exam and marking procedures are given.

A grade scheme is developed in advance for each one of the 12 items, based on the suggestions given by the item writers. The total score is 60 points. Each item has 6 bands ( 0 to 5$)$, updated by the raters after inspection of a sample of actual exam papers. Answers not predicted by the grade schemes are discussed and the grade schemes immediately updated. Double grading is done to ensure reliability. No pre-testing is

\footnotetext{
${ }^{8}$ The candidate is eliminated only if his score is zero.
} 
conducted for confidentiality reasons. The same pair of raters marks the same item in all papers. Depending on item difficulty, two or three pairs of raters are allocated to correct the same item. Statistical analysis is run after marking is completed and the results used for exam analysis and improvement of future applications.

There has not been a tradition in Brazil in producing materials for exam preparation. Some compilation of well known entrance exam papers is usually done by the preparatory schools as part of the materials produced. A few source books containing annotated items of past exams and examples of responses considered adequate and inadequate have been compiled by Unicamp in order to illustrate the marking procedures and the underlying view of reading.

\section{The research purpose and methodology}

The purpose of the study was to gather evidence of the impact of the exam on teachers attitudes as well as on their behaviors and actions or, more specifically, on the content and materials of classes, i.e. in what they taught, as well as on their approach (view of language and reading) and methodology (activities and techniques), i.e., how they taught.

Three different settings were chosen to represent EFL at the secondary level in Brazil: an upper middle-class private school (setting A), with about 30 students in each class and good facilities, which includes access to the Internet; a typical public school (setting B), located in a middle-class neighborhood, with classes of 45 students and poor facilities; and a high-ranking private extracurricular institution (setting C) with classes of 70 students. In the first two settings, the focus of the observation was on third grade classes, although a few first grade classes taught by the same teachers were also observed so that the practices could be compared.. The number of classes observed varied depending on the setting - 10, 15 and 9, respectively. In the three settings, the lessons lasted for 50 minutes.

Coincidentally, all of the three teachers had graduated from the same private university in Campinas and were in their forties at the time the data was collected. The private school teacher (teacher A) was female, with a teaching experience of 11 years, the only one to have had a living experience of three years in the United States during the undergraduate years and have taken in-service courses on a regular basis after graduation. She communicated well in English, the only of the three to conduct most of the classes in English. She taught 18 hours per week. The public school teacher (teacher B) was female with a teaching experience of 7 years in public and private schools. She taught 34 hours per week in 15 classes. The preparatory school teacher (teacher C), on the other hand, was male, with a teaching experience of 19 years in public and private schools. He taught long hours per week ( 72 hours in 57 classes).

The study triangulates information from different perspectives and methods of data collection: a) an analysis of documents, which include exam guidelines, samples from past exam papers, source books containing annotated exam items, as well as São Paulo State Secretary of Education guidelines for English teaching ${ }^{9}$; b) a questionnaire for collecting teachers' information, including past learning and teaching experiences and educational background; c) tape recorded interviews ${ }^{10}$ geared to assess teachers' attitudes towards the exam and its guidelines as well as perceptions of impact (see copy of schedule in Appendix A); d) an interview with a group of students ${ }^{11}$ in setting

\footnotetext{
${ }^{9}$ The focus here is also on reading, although the teaching of other skills is suggested.

${ }^{10}$ Conducted individually with teacher $\mathrm{A}$ an $\mathrm{B}$; teacher $\mathrm{C}$ was not available and answered the questions in writing.

${ }^{11}$ Not originally planned but necessary to complement some of the information provided by teacher B
} 
B (see copy of schedule in Appendix B); and e) classroom observation (field notes and audio recordings). As the research was qualitative and exploratory, to be confirmed later by further studies, there was no pre-determined observation scheme for describing classroom events.

As no baseline data was available, I had to take the teachers' word for describing their practices prior to the introduction of the exam.

Before proceeding to the results, it is important to point out that the type of washback predicted in this study was more specific than just evidence that the teachers were working harder and preparing their classes better because of the exam; it would entail changes in teachers' attitudes and beliefs towards reading and reading comprehension as well as changes in their exam preparation practices motivated by the innovations introduced in the exam. The central assumption here is that the lessons should include reading activities based on materials similar to those found in the Unicamp exam, be geared towards the development of reading as a process of meaning construction, requiring active readers able to use previous knowledge to interact with texts, and allow varied reading whenever possible depending on the purpose and level of comprehension, with answers to be judged according to their adequacy to the reading purpose. Considering the features of the exam and the proficiency levels in English of Brazilian secondary level students, the practice predicted should also provide the means for building up language proficiency while, at the same time, develop strategies which should include dealing with the organization and purpose of authentic texts of different genres, lengths, levels of difficulty, topics and sources. The reading abilities foreseen included explicit and implicit or inferential aspects, global and local comprehension as well as micro and macro level skills (see Section 3).

\section{Results \\ Interviews: teachers' attitudes and perceptions of impact}

The interview data showed concern with university entrance examinations in general and with Unicamp's more specifically to be greatest in setting $\mathrm{C}$ and only beginning to appear in $\mathrm{B}$, with the private school somewhere in the middle. Teacher $\mathrm{C}$ notes that in his setting, everybody, including parents, school, teachers and students show concern about the exams: "it is difficult to have a class in which you do not mention Unicamp, etc". Teacher A's situation is similar: in spite of her school's tradition of preparing students "for life" and not just for entrance examinations, she feels some things have changed in the last years, for concern with entrance examinations seems to be increasing. In her words, "we have now a review course" and "the percentage of how many students we put in is calculated every year". Further, "in the first issue of the school newspaper there was an interview with the students who got in. You cannot create an island, the entrance exam is a reality!".

Teacher B, on the other hand, says that

I try ... I try to gear my classes ... towards entrance examinations because for us now it seems to be the student's aims ... The student is not worried yet with what he is going to use ... let's say English for working in the future ... because that is not very much his reality ... there are a few exceptions ... The people are in fact more concerned about entrance examinations ... Then I try to gear the activities I give to entrance examinations ... Many of them are not thinking about that but I realize that every year there is an increase in the number of students concerned about entrance examinations. 
The student interview data confirms teacher B's perceptions about the increasing importance of those exams in this setting as well. Although many students recognize the possibility of taking those exams, the Unicamp exam is not cited as one of them, since it is seen as difficult and the preparation they were receiving not adequate. Attending intensive preparatory courses was considered necessary for passing. Negative attitudes towards English, learning English and English classes were also made explicit.

Teacher B mentions her difficulty in interpreting the Unicamp guidelines for the English exam:

not even for the teacher ... is ... I feel they [the students] start turning the pages sort of lost. It is not very clear. I did not think very clear ... no. And not even for the teacher ... I don't know, it looks like something kind of ... technical. I think if it were something more objective ... That's it ...you know. In a more accessible language for the student ... for the student.

This opinion, however, is not shared by the other two teachers, who find the guidelines very clear. In teacher A's own words,

For us it is very clear ... not only in my area [English] but in the others as well. Our guidelines are in line with what Unicamp asks for ... Therefore I did not have to make any adaptation for the Unicamp exam ... sometimes I have to adapt myself to other entrance examinations. The problem is the multiple choice ones.

Teacher C's opinion towards the Unicamp exam is very positive. "It's the best in the country because it calls for reading ability, vocabulary and grammar in the texts". Further, "Before the Unicamp exam was introduced, my classes used to be different, as the comprehension questions and also the answers were in English".

All of the teachers seem to recognize that the emphasis given to reading in their classes has to do with the importance this ability receives in the Unicamp exam. In teacher C's own words, “it's a very intense effect". Nevertheless, in spite of mentioning the impact of those exams in gearing her activities, teacher B recognizes using the Unicamp exam only when preparing materials to complement her lessons, "as I use The State Secretary of Education guidelines and the textbook when preparing my classes".

Teacher $\mathrm{B}$ and $\mathrm{C}$ also recognize that besides reading activities, their lessons include grammar, which is justified, in the first case, by virtue of its being contained in the São Paulo State Secretary of Education teaching guidelines, and, in the second, for being a subject matter assessed by other examinations which include explicit grammar multiple choice items. Teacher A, on the other hand, declares that "as the years go by, I try to run from grammar, but there is no way to run from it! Further "for me, it's a parenthesis: I open the parenthesis, give grammar and come back to the real world".

Teacher C's materials are prepared by the teacher's institution; "all I can do is to suggest a few texts", he adds. On the other hand, teacher A declares that although the objectives and the materials of her classes are based on the school guidelines, and despite the fact she has weekly discussions with a coordinator about those aspects, including methodology and assessment procedures, she recognizes that "[the coordinator] does not take part in the effective planning of my classes".

The three teachers recognize that the methodology used in the classes is their choice and, as such, does not receive influence of any sort. In order to illustrate her 
argument, teacher A declares using "different methods" when working with texts: "presenting the vocabulary to introduce the topic before reading the text, asking the students to do individual silent reading or to read the questions before reading the text".

To the questions aimed at revealing the teachers' view or underlying concept of reading, teacher B answered that "it is something very important which builds vocabulary and helps the production of new texts". Working with texts is seen as "important because the student learns two things at the same time: translation and grammar". Among her criteria for text selection, "grammar figures in the first place and student interest in the topic in the second". Teacher C, on the other hand, defines reading as a "an efficient means of building knowledge and also of self-instruction" while teacher A as "something which transports me to another place, involves me, and leads me to re-evaluate myself as a human being".

In trying to articulate a response to express their understanding of the view of reading underlying the exam, the aspects perceived as most distinctive differed among the teachers: while for teachers A and C they were the authenticity and the diversity of texts in terms of topics, lengths, sources, genres and levels of difficulty, the method of testing using open-ended questions and Portuguese in the rubrics and in the questions/answers, for teacher B it was the variation in text topic. Yet, none of the teachers seemed to have understood the significance of these features or their implication for the view of reading underlying the exam.

\section{Classroom observation: exam impact on teachers' behaviors and actions}

Classroom observation data, consisting of field notes and tape recordings showed teacher C and teacher B's practices to be similar in the sense that they are both dictated by ready-made materials and, consequently, evidenced little variation or innovation. Time spent in reading activities, nevertheless, varied in the two contexts as teacher $\mathrm{C}$ balances reading and grammar activities, which are taught separately, and teacher B spends most of the time on grammar activities.

Teacher C's materials contain two parts: grammar rules, followed by fill-in-theblanks and multiple choice exercises; and texts, generally authentic, of different topics and types, accompanied by a glossary of words and expressions, a list of irregular verbs and two multiple choice comprehension questions in Portuguese, aimed at assessing location of explicit information. Some of the reading passages contained in the materials were extracted from past exam papers of different entrance examinations, including Unicamp's. Analysis of a Unicamp mock exam designed by the teacher shows that although the reading passages were of different types, lengths and topics and, as such, similar to those found in the Unicamp exam, the purpose of the items was limited to location of explicit information.

Teacher B, in the same way, follows the activities proposed by the book, which is structured as follows: texts specially created for the textbook, followed by comprehension questions using true or false, multiple choice and short answers; exercises of completing sentences with words from the text, finding the opposites and practicing with the structures of the text. In the last part of the unit there is a section entitled Reading for Information, in which the texts are authentic and the rubrics, as well as questions and answers to the questions, unlike other parts, are in Portuguese. As in the other setting, all of the comprehension questions are aimed at assessing explicit information. 
In working with texts, the methods of teachers $\mathrm{B}$ and $\mathrm{C}$ are also very similar, as they read and translate the text to the class. Teacher $\mathrm{C}$ usually does it quickly and answers the comprehension questions, which are in turn copied by the students. Teacher B, on one occasion, spent the whole class period attempting to translate the text by asking the students the meaning of the words. Although she eventually called their attention to a few cognates, false-cognates and suffixes as a way to infer word meaning, she failed to articulate the notion of vocabulary inference in a systematic way. As the students' vocabulary is limited, this process became long and straining, and the teacher ended up translating the text herself, which was readily copied by the students. As the class was noisy, some of those students eventually ended up missing parts of the translation, and insistent pleas for the teacher to repeat the missing parts were heard. Copying the translation was the most important activity. The explanation for this copying activity became evident when the teacher gave the test, which contained a reading passage directly extracted from the textbook. After translation was completed, the students answered the comprehension questions and did the other exercises. As the questions assessed location of explicit information, there was no discussion as to what the most adequate answer should have been.

A few differences can be observed when teacher A's practice is compared to the other two. Although grammar is also approached in the traditional way, through explanation of rules, followed by exercises, it deserves little attention in teacher A's lessons, most of the time being spent on reading activities, done individually or in pairs in class or as homework, containing reading passages similar to those found in the Unicamp's exam, followed by some activity, usually comprehension questions. Despite of the similarities in the reading materials, the items are different, and in this way, similar to the ones in setting $\mathrm{C}$, in that they are not aimed at building up different sub-skills or at exploring different strategies and text organizations when dealing with different text types. The answers are corrected on the blackboard in terms of right or wrong and the responses considered "good" by the teacher (the criteria being those which "read well" and use "the correct terminology") are emphasized. Only parts of the text focused on by the questions are discussed; most of the time, they end up being translated. Some of the answers are given in Portuguese, others in English.

Oral production activities were not observed in the third grade, and their absence is justified by the teacher in terms of their irrelevance for entrance examinations. Some oral production, however, was observed in first grade classes taught by the same teacher. Extensive reading on one occasion was done through the Internet in order to research a topic and it was followed by writing summaries or compilations in groups.

Although exam-related activities did not seem to be planned as part of the lessons, advise such as "read attentively the question before answering", "write the answers in clear Portuguese" and "give complete answers, with all the necessary elements", linked to the Unicamp exam, were frequent in setting $\mathrm{A}$ and less frequent $\mathrm{C}$, but absent in $\mathrm{B}$, and could possibly be interpreted as evidence of negative washback.

\section{Discussion}

The interview and classroom data seem to suggest evidence of a Unicamp exam washback on teachers' attitudes as well as on their practices. However, washback in this case could be said to be partial or limited, as it seems to reflect some but not all of the important and distinctive aspects of the exam, and to have differential intensity (Scaramucci, 1998, 1999a), as some aspects are present in the private school setting and absent in the public school setting, with the preparatory school somewhere in the middle. The aspects perceived by the teachers and confirmed by classroom data as affecting their practices were a) the skill focused (reading); b) the authenticity of the 
texts and the diversity in terms of subject matters, genres, sources, lengths and levels of difficulty; c) the use of Portuguese in questions and answers, as well as in the rubrics; and e) the method of testing using open-ended questions.

Although teacher's A practice can be said to be different when compared to the other two, reflecting more closely some of those features of the Unicamp exam, it is similar in the following aspects: the use of reading passages with comprehension questions focusing on the location of explicit information and which have only one possible correct answer, grammar taught as a separate subject matter without attempting to relate it to meaning, and emphasis on translation. All of these aspects suggest a view of reading as a process of decoding which is concerned only with language proficiency and which does not need to be taught but just tested.

Therefore, these results may be taken as evidence to affirm that the more implicit aspects of the exam, i.e., the underlying view of reading, seen as an ability involving higher-level and lower-level skills that need to be developed, does not seem to be perceived by the teachers as something distinct from what they have been doing all along. Consequently, the influence of the exam on their teaching approach and methodology (Scaramucci, 1998, 1999 a, 1999b) appears to be minimal.

Considering the fact that Unicamp does not offer any guidance to teaching aside from guidelines for testing, a teaching methodology would have, in this case, to be developed by the teachers or material writers considering the principles and the underlying theoretical assumptions concerning reading. Although I agree with teacher A that many methods can be used for preparing students for this exam, I must emphasize that they all must be based on a view of reading as meaning construction.

The existence of a stronger although limited washback in the private school setting as well as the good performance of the students on the exam could be explained by what I consider to be an interplay of favorable conditions present in this setting, as evidenced by the analysis of questionnaire, interviews and classroom observation data, which include: teacher education, involving a good command of English; opportunity to reflect upon and discuss theoretical and practical aspects of practice with a coordinator; the opportunity and time to prepare one's own teaching materials and to take in-service courses; good working conditions, including fewer hours of teaching and facilities such as access to newspapers, magazines and the Internet as sources of materials for classes; school guidelines more in line with Unicamp's; the significance attached by students, parents and school to higher education, foreign languages and entrance examinations, and the trust in the education provided by the school as a route to higher education; motivated students with high self-esteem and confidence in the preparation received at school; and teachers' good expectations regarding the students' chances to succeed in the examination. The lack of these conditions would explain the weakest washback in the public school setting as well the lack of interest and poor performance of the students on the exam. In the cramming course setting, favorable and unfavorable conditions could explain the washback somewhere in the middle, as well as the better performance of the students on the exam when compared to the ones from the public setting, despite the fact that the teaching practices were found to be similar in the two settings. Nevertheless, to interpret this as evidence that teacher education can be outweighed by other factors does not seem plausible; it would be more reasonable to hypothesize that if teacher methodology were more in line with the concept of reading underlying the exam, the performance of the students in the exam could be even better.

\section{Conclusion}


The conclusion of this study, aimed at investigating the impact of a reading ability exam on three settings of EFL teaching at the secondary level in Brazil is that despite the fact that the exam is theoretically oriented towards current views of the reading process and has been in use for over a decade, it failed to change the beliefs of the teachers regarding reading and the teaching of reading, which still seems to be viewed as a passive process of decoding, following the tradition of teaching reading in the mother tongue in first and secondary levels as well as of foreign languages in Brazil.

These results could be interpreted as evidence against a deterministic view of washback and in favor of one which recognizes, as others have done (Gimenez, 1999; Wall \& Alderson, 1992; Watanabe, 1996), the importance of teacher personal beliefs and educational background, among others, as mediating factors between the exam and the type and amount of washback produced. It can also be said to provide evidence to confirm the hypothesis suggested by Alderson and Wall (1992) and expanded by Hamp-Lyons and Alderson (1996:296) that "Tests will have different amounts and types of washback on some teachers and learners than on other teachers and learners".

Before we can generalize these results and accept them as real contributions to a washback theory, it is important to recognize their limitations, due to the fact that this is an exploratory and qualitative, small scale case study with only three subjects and, as such, in need of confirmation by further studies using different methodologies conducted with many more teachers involved in other teaching and testing contexts in Brazil.

\section{References}

ALDERSON, J.C. \& WALL, D. Does washback exist? Working Paper Series, v. 11. CRILE, Lancaster University, 1992.

ALDERSON, J.C. \& HAMP-LYONS, L. TOEFL preparation courses: a study of washback. Language Testing, v. 13, p. 280-297, 1996.

CONSOLO, D.A. O livro didático como insumo na aula de língua estrangeira (Inglês) na escola pública. [The textbook as input in EFL classes in the public schools]. 1990. Dissertação [Master Thesis], (Mestrado em Lingüística Aplicada) - Instituto de Estudos da Linguagem, Unicamp, Campinas.

GIMENEZ, T. Concepções de linguagem e ensino na preparação de alunos para o vestibular [Underlying concepts of language and teaching in student preparation for university entrance examinations]. Trabalhos em Lingüística Aplicada, v.34, p 21-37, 1999.

Ministério da Educação [Ministry of Education]. Fonte [Source]: MEC/INEP, 2000.

São Paulo (Estado) Secretaria da Educação. Coordenadoria de Normas Pedagógicas. Proposta curricular de Língua Estrangeira Moderna - Inglês: $2^{\circ}$ grau. [Modern Foreign Language Curriculum Guidelines - English: secondary level] Segunda edição, São Paulo:SE/CENP,1992.

SCARAMUCCI, M.V.R. University entrance examinations and EFL teaching: a study of washback in the Brazilian context. Paper presented at the $12^{\text {th }}$ World Congress of Applied Linguistics (AILA99), Tokyo, Japan, 1999a. 
Vestibular e ensino de inglês em uma escola pública [University entrance examination and the teaching of English in a public school]. Trabalhos em Lingüistica Aplicada, v. 34, p. 7-20, 1999b.

O efeito retroativo dos vestibulares de língua inglesa da Unicamp no ensino de segundo grau de escolas públicas e particulares de Campinas [The washback effect of the Unicamp EFL exam on secondary level teaching of public and private schools in Campinas]. Unpublished report, FAPESP 95/06551-9, 1998.

Vestibular Nacional Unicamp. Manual do candidato (1996). [Unicamp national entrance examination. Candidate's manual]. Comvest, Unicamp.

WALL, D. \& J.C. ALDERSON. Examining washback: The Sri Lankan impact study. Working Paper Series, v.12. CRILE, Lancaster University, 1992.

WATANABE, Y. Does grammar translation come from the entrance examination? Preliminary findings from classroom-based research. Language Testing, v. 13, p. 318332, 1996.

\section{Appendix A}

\section{Prompts for individual interviews with teachers}

1. Do you follow guidelines when planning your classes? Please explain your answer.

2. Are you familiar with the São Paulo State Secretary of Education guidelines for English teaching? Do you take it into account when planning your classes? Please explain your answer briefly.

3. What sort of materials do you use in your classes?

4. How do you describe your methodology? Can you choose your own methodology?

5. Do you believe entrance examinations such as Unicamp's and others have a influence on your classes? Please explain your answer.

6. Do you think you would teach better if there were no entrance exams? Please explain your answer.

7. Are you concerned about those exams when teaching your classes? And the students? And the parents? And the school?

8. What is your opinion of the Unicamp exam? And of the other exams? How do you compare the Unicamp exam to the others in terms of difficulty?

9. What do you think of the fact that it is a reading test?

10. What is the view or definition of reading underlying the Unicamp exam?

11. What sorts of knowledge do you consider necessary for doing well in such an exam?

12. In your opinion, what is the best way to prepare students for this exam?

13. Do you think this exam influences the content and materials of your classes (what your teach)? And your approach and methodology (the way you teach)? Please explain your answer.

14. What were your classes like before the introduction of this exam?

15. How do your students do in this exam? And in the others?

16. Are the Unicamp guidelines clear enough to you? And to your students?

17. What is your definition of reading?

18. What is involved in teaching reading in English? How do you proceed? 
19. Do you think you're well prepared to teach reading in English? Please explain your answer.

20. How do you select your texts?

\section{Appendix B \\ Schedule for interview in group with students}

1. Average age

2. Parents' occupation

3. Students' occupation

4. Plans after finishing secondary school

5. Entrance exams taken

6. Familiarity with the Unicamp exam

7. Attitudes towards school and exam preparation

8. Attitudes towards English, learning English and English classes 